\title{
Modern trends in technical support of agricultural producers
}

\author{
Nail Asadullin*, Farit Mukhametgaliev, Fayaz Avkhadiev, Marcel Khismatullin and Ilgizar Gainutdinov \\ Kazan State Agrarian University, Kazan, 420015, Russia
}

\begin{abstract}
In modern conditions of the development of an innovative economy, the scientific literature does not reveal the main problems of strengthening the material and technical base of agricultural producers. The agricultural machinery market is practically absent, the issue of formation and functioning remains unresolved. The article is devoted to the assessment of the current state of the provision of agricultural commodity producers with equipment, the development of the tractor and agricultural machine-building industry in Russia, the disclosure of problems, and the search for solutions to the problem of complex mechanization of agriculture in modern conditions. The scientific novelty of the work is determined by the substantiation of the need to solve the problems of strengthening the material and technical base of the subjects of agricultural business and the proposed practical recommendations for the development of the innovative basis of agriculture. The article reveals the main trends in the change in the output of elements of the material and technical base of agriculture, reveals the problems that restrain the process of technical renewal of agricultural production, suggests ways to increase the provision of technical means for the innovative development of the agrarian sector of the economy. The theoretical and practical results of the study can be recommended for use in the formation of programs for the development of technical equipment in the agricultural sector, planning of agricultural production, economic analysis of the economic activities of agricultural enterprises and organizations.
\end{abstract}

\section{Introduction}

One of the priority directions of agricultural development is stable technical support for business development. The solution to this problem largely depends on the use of the structural elements of the technical base, on the conditions of its operation and reproduction, on the susceptibility to various innovations, and the high adaptability to the changing external environment. Ultimately, this becomes possible by strengthening the material and technical base of agricultural producers, aimed at introducing modern resource-saving technologies and rational highly efficient machinery, agricultural machinery, and equipment into production. Agriculture is the central link in the agro-industrial complex, an important source of income, and a tool for ensuring the country's food security. In modern research works, the fundamentals of the problems of developing the technical base of the sector of the agrarian economy are practically not disclosed. Issues related to the formation and functioning of the agricultural machinery market remain unresolved. At the present stage of the development of technical modernization of the agro-industrial complex, the trends in the development of the tractor and agricultural engineering industry on a global scale are aimed at automation, robotization, and digitalization of technological processes in agricultural production. All this is done to maximize the benefits of modernized agricultural machines, minimize human participation directly in the production environment with biological factors of agricultural production, reduce the influence of the human factor on the quality and accuracy of compliance with agro-technical measures. Not only the development of the agro-industrial complex but also the improvement of the quality of life of people in rural areas, the level of provision of the country's population with food products depends on the achievement of these goals and the solution of the problem of effective use of the modernized technical base [1-3]. In this regard, the search for ways to solve the problem of complex mechanization of agriculture becomes especially relevant in modern conditions.

\section{Materials and Methods}

The theoretical and methodological basis of the research is based on the use of the possibility of interaction and complementarity of the fundamental provisions and concepts of economic theory. The general methodological basis of the research is system analysis. The extensive material and the variety of their content have made it necessary to use various approaches, methods, and techniques of scientific research within the framework of system analysis, such as constructive, deterministic, retrospective, dynamic, and statistical. During the study, methods of disclosing trends in the development of agri-food policy and the peculiarities of their manifestation were used: monographic, abstract-

\footnotetext{
Corresponding author: slonopotam1963@yandex.ru
} 
logical, computational-constructive, economic and statistical, analogies. Official data of the Federal State Statistics Service of the Russian Federation, the Ministry of Agriculture of the Russian Federation, data obtained during the author's analysis and calculations were used as an information base for the study.

\section{Results}

In the context of geopolitical risks and sanctions from a few Western countries, the agro-industrial complex of Russia faces the task of more complete provision of the population with food and sustainable socio-economic development of rural areas through the widespread introduction of innovative technologies and more productive rational technologies for the use of agricultural machines [1-3].

The results of the reforms carried out in the country on the transition from a planned balanced economy to the principles of market self-regulation of the development of economic sectors turned out to be catastrophic, primarily for the agricultural sectors of the economy. Adopted and implemented over the past 30 years, credit and financial, investment and innovation, budgetary policies, high inflation rates and the unrestrained rise in prices for goods serving agriculture, industries, fuels and lubricants, fertilizers have contributed to the irreparable destruction of the existing material and technical base of agricultural production [4-6]. The limited financial resources due to incomparably low prices for agricultural products, old irrational equipment, and technologies corroded internal reserves to strengthen the material and technical potential, ensuring the sustainable development of this vital industry and the sphere of life of a quarter of the country's population. The simple comparable calculations made allow us to conclude that during this period of restructuring of the country's economy, the material and technical base of agricultural production and its foundation, represented by tractor and agricultural engineering, has been destroyed [7, 8]. This is evidenced by the indicators of production and output of power units in the form of tractors for the agricultural sector of the economy, which by 2019 decreased by more than 21 times to the level of the beginning of reforms, tillage machines in the form of plows of various modifications and classes - by 77.9, harvesting equipment, as grain harvesters - 9.8 times, the main equipment for livestock in the form of milking machines -51.1 times [9]. The reduction is practically observed in all types of equipment. This can be regarded as the degradation of domestic agricultural engineering and as one of the most important constraints on the progressive sustainable development of the country's agro-industrial complex. A similar situation is observed with agricultural harvesters. As a result, the level of technical support for agricultural producers in Russia is at an unacceptably low level. Today, per 1000 hectares of arable land in our country, there are only 3 tractors, and in Canada, with conditions like Russia in terms of soil and climatic parameters, arable land productivity, and all indicators of the norm-forming factors of fields, there are 16 tractors $[9,10]$. The difference is more than five times. The most unpleasant thing in this process is that the current trend continues at present, as evidenced by the indicators of the state of production of basic agricultural machinery and equipment for agricultural business entities, shown in Table 1.

Table 1. Indicators of the output of the main types of agricultural machinery and equipment in Russia, pcs. [10]

\begin{tabular}{|c|c|c|c|}
\hline Types of equipment & $\mathbf{2 0 1 7}$ & $\mathbf{2 0 1 8}$ & $\mathbf{2 0 1 9}$ \\
\hline $\begin{array}{c}\text { Tractors for agriculture, thousand } \\
\text { units }\end{array}$ & 7300 & 7100 & 6600 \\
\hline Combine harvesters & 7606 & 4628 & 4830 \\
\hline $\begin{array}{c}\text { Machines for harvesting and } \\
\text { primary processing of corn }\end{array}$ & 200 & 47 & 109 \\
\hline $\begin{array}{c}\text { General purpose plows, thousand } \\
\text { units }\end{array}$ & 21 & 19.7 & 23.7 \\
\hline Seeders & 8674 & 8895 & 8540 \\
\hline $\begin{array}{c}\text { Mowers (including cutting devices } \\
\text { for installation on a tractor) }\end{array}$ & 6573 & 5725 & 5576 \\
\hline Cultivators, thousand units & 49.5 & 36.2 & 42.5 \\
\hline Milking machines & 3884 & 3250 & 2544 \\
\hline
\end{tabular}

The table shows, unfortunately, for all types of agricultural machinery and equipment, the decline in production continues, especially for equipment designed for harvesting the grown crop. In 2019, Russia produced 6,600 tractors, a decrease compared to 2017 by $9.6 \%$, 4,830 grain harvesters $(-36.5 \%), 5,576$ mowers $(-15.2 \%)$, seeders 8540 pcs. $(-1.6 \%), 42.5$ thousand cultivators. (-14.2\%), milking machines 2544 pcs. $(-34.5 \%)$. According to the analytical company ASMHolding, "in Russia in 2019, in the total number of tractors produced this year, the share of domestic brands was $46 \%$, foreign cars assembled in Russia - 54\%, of which: assembly from tractor sets MTZ - 30,7 \%, from sets of KhTZ - 1.8, from sets of foreign brands (Versatile, New Holland, Agrotron, Axion, John Deere, Xerion) $-21.5 \%$. An increase in the production of tractors compared to the data of the corresponding period of 2017 was noted at the St. Petersburg Tractor Plant $(+14.2 \%)$, Cherepovets Foundry and Mechanical $(+18.8 \%)$, Combine Rostselmash (+14.2\%), John Deere Rus - $(+48.8 \%)$, CLAAS (+45.3\%), Kovrov Electromechanical Plant, DST Ural (+ $72.1 \%)$, Promtraktor $(+8.3 \%)$, self-propelled vehicle plants $(+31.4 \%)$ and Altailesmash (growth by 2.1 times), the Chelyabinsk plant of industrial tractors (+63.2\%" [11].

Fulfillment of high requirements for the quality of food products and agricultural labor in today's conditions is possible only using remote control systems, control, careful monitoring of technical parameters, adjustments of agricultural machines in accordance with the state of natural biological and climatic factors of production. Along with this, important aspects remain the achievement of high results in the operation of equipment, such as an increase in the output of agricultural machines, rationalization of the performance of technological operations, an increase in the productivity of performers, compliance with the safety requirements of personnel and the parameters of the 
ergonomics of the working environment, the implementation of environmental requirements for environmental protection, the transition to a lean method of use. material and financial resources, the use of composite materials, and additive (3-D) technologies. The solution to these problems largely depends on the use of the structural elements of the technical base, on the conditions of its operation and reproduction, on the susceptibility to various innovations, and the high adaptability to the changing external environment $[12,13]$.

Analysis of the dynamics of the provision of agricultural producers shows that for the period from 2000 to 2019 , the number of physical tractors decreased 3.6 times, grain harvesters - 3.6 times, self-propelled forage harvesters -5.0 times, potato harvesters -5 times, 9 times, sugar beet harvesters -6 times, sprinklers and irrigation machines -3 times, milking machines and aggregates -4 times (Table 1 ).

Table 2. Park of the main types of equipment in agricultural organizations (at the end of the year; thousand units) [10]

\begin{tabular}{|c|c|c|c|c|c|}
\hline \multirow{2}{*}{ Types of equipment } & \multicolumn{5}{|c|}{ Years } \\
\cline { 2 - 6 } & $\mathbf{2 0 0 0}$ & $\mathbf{2 0 1 6}$ & $\mathbf{2 0 1 7}$ & $\mathbf{2 0 1 8}$ & $\mathbf{2 0 1 9}$ \\
\hline Tractors2) & 746.7 & 223.4 & 216.8 & 211.9 & 206.7 \\
\hline Plows & 237.6 & 61.6 & 59.7 & 58.5 & 56.9 \\
\hline Cultivators & 260.1 & 90.3 & 87.6 & 84.8 & 82.6 \\
\hline Seeders & 314.9 & 87.8 & 82.8 & 79.0 & 74.8 \\
\hline Combines: & & & & & \\
\hline grain harvesting & 198.7 & 59.3 & 57.6 & 56.9 & 55.0 \\
\hline corn harvesting & 4.4 & 0.7 & 0.7 & 0.6 & 0.6 \\
\hline forage harvesting & 59.6 & 13.3 & 12.7 & 12.3 & 11.8 \\
\hline potato harvesting & 10.0 & 2.2 & 2.1 & 2.0 & 2.0 \\
\hline flax harvesting & 3.2 & 0.3 & 0.3 & 0.3 & 0.2 \\
\hline $\begin{array}{c}\text { Beet harvesters } \\
\text { (without toppers) }\end{array}$ & 12.5 & 2.2 & 2.2 & 2.1 & 2.1 \\
\hline Mowers & 98.4 & 31.0 & 30.5 & 30.1 & 29.8 \\
\hline Balers & 44.0 & 20.4 & 19.9 & 19.6 & 19.5 \\
\hline Roller headers & 85.2 & 19.0 & 19.1 & 18.8 & 19.1 \\
\hline $\begin{array}{c}\text { Sprinklers and } \\
\text { irrigation machines and } \\
\text { installations }\end{array}$ & 19.2 & 6.0 & 6.2 & 6.1 & 6.4 \\
\hline $\begin{array}{c}\text { Spreaders of solid } \\
\text { mineral fertilizers }\end{array}$ & 34.3 & 15.7 & 15.5 & 15.7 & 15.7 \\
\hline $\begin{array}{c}\text { Machines for applying } \\
\text { organic fertilizers to the } \\
\text { soil: }\end{array}$ & & & & & \\
\hline solid & 22.0 & 4.7 & 4.7 & 4.5 & 4.5 \\
\hline liquid & 12.1 & 3.6 & 3.7 & 3.8 & 4.1 \\
\hline $\begin{array}{c}\text { Tractor sprayers and } \\
\text { pollinators }\end{array}$ & 32.5 & 22.8 & 23.1 & 23.5 & 24.3 \\
\hline $\begin{array}{c}\text { Milking machines and } \\
\text { aggregates }\end{array}$ & 88.7 & 24.1 & 22.9 & 22.4 & 21.9 \\
\hline
\end{tabular}

If we consider the changes over the last year, then in 2019 in the agricultural sector there is a decrease in the number of tractors by 5.2 thousand units, grain harvesters - by 1.9 thousand units. and self-propelled forage harvesters - by 0.5 thousand units. [fourteen]. Along with this, in the agricultural sector of the economy, the rate of renewal of equipment and fixed assets remains extremely low. In 2019, it was only $3 \%$, and for the normal reproduction process to be at least
$12.5 \%$ [15]. The consequence of this phenomenon was the rapid increase in material and moral wear and tear of the elements of the material and technical base of agricultural production. Ultimately, the low level of renewal led to the fact that the elements of material and technical potential used in the sphere of material production of the agrarian sector of the economy have developed their standard amortization period by about $60 \%$ (Table 3).

Table 3. Distribution of the main types of equipment with a service life of more than 10 years by federal districts of the Russian Federation, \% [14]

\begin{tabular}{|c|c|c|c|c|c|c|}
\hline Federal district & $\begin{array}{c}\text { Tractors in } \\
\text { the agro- } \\
\text { industrial } \\
\text { complex, \% }\end{array}$ & $\begin{array}{c}\text { Combine } \\
\text { harvesters, } \\
\text { \% }\end{array}$ & \multicolumn{2}{|c|}{$\begin{array}{c}\text { Forage } \\
\text { harvesters, } \\
\text { \% }\end{array}$} \\
\cline { 2 - 7 } & $\mathbf{2 0 1 8}$ & $\mathbf{2 0 1 9}$ & $\mathbf{2 0 1 8}$ & $\mathbf{2 0 1 9}$ & $\mathbf{2 0 1 8}$ & $\mathbf{2 0 1 9}$ \\
\hline $\begin{array}{c}\text { Russian } \\
\text { Federation }\end{array}$ & 59.8 & 59.2 & 45.1 & 44.4 & 42.7 & 41.7 \\
\hline Central & 54.4 & 53.6 & 40.2 & 38.6 & 41.5 & 41.0 \\
\hline Northwestern & 52.4 & 54.8 & 40.8 & 41.9 & 44.7 & 48.1 \\
\hline Southern & 62.1 & 58.1 & 47.1 & 45.7 & 57.5 & 51.7 \\
\hline North Caucasian & 52.6 & 52.6 & 37.9 & 41.5 & 60.1 & 64.2 \\
\hline Privolzhsky & 60.8 & 59.7 & 44.4 & 45.3 & 45.0 & 43.0 \\
\hline Ural & 66.6 & 65.5 & 53.7 & 55.3 & 46.6 & 47.5 \\
\hline Siberian & 67.5 & 66.0 & 50.3 & 46.1 & 28.3 & 27.2 \\
\hline Far Eastern & 50.6 & 48.5 & 37.1 & 38.2 & 41.8 & 41.9 \\
\hline
\end{tabular}

The table shows that the largest number of tractors, since the year of production of which more than ten years have passed, were registered in the Siberian, Ural, and Volga Federal Districts, grain harvesters - in the Ural Federal District and forage harvesters - in the North Caucasian Federal District. The decrease in the share of equipment, more than 10 years have passed since the year of production, is associated with the retirement of equipment of Russian (Soviet) production.

Along with this, to effectively conduct production activities, agricultural producers must update their machine and tractor fleet with a certain amount of new equipment. The corresponding amount of equipment and the security of agricultural production is achieved through the purchase of new machines for supplies from different areas of the agricultural machinery market. Unfortunately, due to the insufficient amount of domestic equipment on the agricultural machinery market and its low competitiveness, agricultural producers are forced to purchase imported machinery. Comparison of the level of development of technical resources of global and Russian agriculture testifies to the inconsistency of domestic equipment for agricultural business with world standards in terms of the corresponding quantitative, qualitative and structural parameters and modern ergonomic and environmental requirements. In particular, the equipment manufactured in our country and used in the domestic agricultural business, in comparison with foreign similar equipment, provides $90 \%$ of potential productivity, $35-40 \%$ of reliability, $40 \%$ of compliance with world standards in terms of the general technical level [15]. To get out of this situation, it is necessary to develop and implement a 
new targeted state program for the development of domestic agricultural engineering and technical modernization of agricultural business entities. In 2019 compared to 2018, the purchase of tractors increased (table 4).

Table 4. Purchase of the main types of agricultural machinery by federal districts [10]

\begin{tabular}{|c|c|c|c|c|c|c|}
\hline \multirow[t]{2}{*}{$\begin{array}{l}\text { Federal } \\
\text { district }\end{array}$} & \multicolumn{3}{|c|}{ Tractors, units } & \multicolumn{3}{|c|}{$\begin{array}{c}\text { Combine harvesters, } \\
\text { units. }\end{array}$} \\
\hline & 2018 & 2019 & $\begin{array}{c}2019 \\
\text { to } \\
2018, \\
\%\end{array}$ & 2018 & 2019 & $\begin{array}{c}2019 \\
\text { to } \\
2018, \\
\%\end{array}$ \\
\hline $\begin{array}{c}\text { Russian } \\
\text { Federation - } \\
\text { total }\end{array}$ & 10472 & 10714 & 102.3 & 5221 & 4627 & 88.1 \\
\hline Central & 2409 & 2279 & 94.6 & 1111 & 979 & 85.6 \\
\hline Northwestern & 368 & 420 & 114.1 & 53 & 50 & 94.3 \\
\hline Southern & 2682 & 2410 & 89.9 & 1251 & 1006 & 80.4 \\
\hline $\begin{array}{c}\text { North } \\
\text { Caucasian }\end{array}$ & 572 & 17 & 90.4 & 388 & 209 & 53.9 \\
\hline Privolzhsky & 2503 & 2932 & 117.1 & 1345 & 1198 & 89.1 \\
\hline Ural & 520 & 584 & 112.3 & 234 & 263 & 112.4 \\
\hline Siberian & 1025 & 1162 & 113.4 & 611 & 719 & 117.7 \\
\hline Far Eastern & 393 & 410 & 104.3 & 228 & 203 & 89 \\
\hline
\end{tabular}

The data in the table show that, in 2019, agricultural business entities in all areas of the agricultural machinery market purchased 10,714 tractors, which is $242(+2.3 \%)$ more than in 2018, 4,627 combine harvesters, which is $594(-11.4 \%)$ less compared to 2018. In addition, 624 forage harvesters were purchased in 2019 ( $4 \%$ less than in 2018).

In the absence of proposals from Russian manufacturers of agricultural machinery, agricultural producers of the Russian Federation, to renew an outdated fleet of agricultural machinery, are forced to purchase expensive imported agricultural machinery not produced in the territory of the Russian Federation or produced with a low level of localization of production $[9,14]$.

At the same time, it is necessary to pay attention once again to the fact that the share of imported machinery in the total number of agricultural types of machinery in 2019 amounted to $73.1 \%$ for tractors (in $2018-70.8 \%$ ), for grain harvesters $-61,5 \%$ (in $2018-59.0 \%$ ) and for forage harvesters $-63.5 \%$ (in $2018-61.8 \%$ ).

To stop the disposal of the main types of agricultural machinery, it is necessary to purchase at least 20.0 thousand units annually. tractors, 8.0 thousand units grain harvesters, and 2.0 thousand units. forage harvesters, as well as have regional programs for technical and technological modernization. This must be done because labor productivity in our agriculture is 11 times lower than in the United States and 7 times lower than in Germany [11].

The main reasons for this situation and the preservation of the trend of degradation of the material and technical base of agriculture should be sought in the results of the unjustified implementation of reforms in the country on the transition from a planned balanced economy to the principles of market self-regulation, which turned out to be catastrophic primarily for agriculture. As a result of price liberalization and the continuing trend of an increasing gap between the prices of industrial goods and agricultural products, the lowpaying capacity of agricultural producers remains. The limited financial resources that continue for a long time do not allow timely updating of old equipment to new, more efficient ones with a robotic control system. In such a situation, it is required to use the mechanism of state regulation of the development of the material and technical base of agricultural business entities.

\section{Conclusion}

The downward trend in the level of provision of material and technical resources in the agricultural sector of the economy continues and it is necessary to radically change the strategy and tactics of the development of domestic tractor and agricultural engineering, as the main condition for the transition to resource-saving technologies in agricultural production, which makes it possible to implement a program of lean production, significantly increase crop yields in crop production and livestock productivity in animal husbandry, product quality of agricultural business entities. Analysis of the current state of the material and technical base of agricultural producers showed that the agricultural sector of the Russian economy today is provided with tractors and the main types of agricultural machinery and equipment by $17-80 \%$ of the standard indicators. Comparison of the level of development of technical resources of global and Russian agriculture testifies to the inconsistency of the material and technical base of the Russian agricultural business with world standards in terms of the corresponding quantitative, qualitative and structural parameters and modern ergonomic and environmental requirements. In particular, the equipment manufactured in our country and used in the domestic agricultural business, in comparison with foreign similar equipment, provides $90 \%$ of potential productivity, $35-40 \%$ of reliability, $40 \%$ of compliance with world standards in terms of the general technical level. According to the strategy for the development of the agricultural business, it is necessary to increase the technical equipment of the industry, but the production of domestic agricultural machinery and equipment is declining. Nevertheless, the purchase of equipment for the agricultural sector of the economy is underway. Our agricultural producers purchase imported highperformance and more modern equipment, thereby investing in the development of the agricultural industry in foreign countries. Will not will, the outflow of capital into the economy of the Western powers is obtained. By purchasing imported equipment, it is ultimately possible to maintain the level of energy supply of the domestic agricultural business at the same level over the past years. It is necessary to develop and implement a new targeted state program for the development of domestic agricultural engineering and technical modernization of agricultural business entities. 


\section{References}

1. D.F. Khafizov, Features of the current stage of development of a mixed economy, Bull. of Kazan State Agrar. Univ., 3, 157-161 (2018)

2. D.F. Khafizov, Issues of development of small businesses and cooperation in rural areas, Bull. of Kazan State Agrar. Univ., 1, 138-144 (2019)

3. F.N. Mukhametgaliev, Agrarian transformations in the Republic of Tatarstan, agro-industrial complex, Econ., manag., 4, 38 (2005)

4. L.R. Bilalova, Strategic enterprise management in the agro-industrial complex, Vector of econ., 4, 67 (2018)

5. L.F. Sitdikova, Main directions of technical modernization of agriculture of the Republic of Tatarstan, Techn. and equip. for rural areas, $\mathbf{4}$, 46-48 (2017)

6. F.F. Sadrieva, Problems of technical support of agriculture of the Republic of Tatarstan, Bull. of Kazan State Agrar. Univ., 2, 121-125 (2017)

7. R.G. Khisamov, Leasing of equipment and technologies as a tool for the development of agroindustrial production, Bull. of Kazan State Agrar. Univ., 2, 31-35 (2015)

8. R.K. Sitdikov, Technical equipment of the agroindustrial complex of the Republic of Tatarstan, Rural mech., 11, 8-9 (2013)
9. Federal State Statistics Service of the Russian Federation, Retrieved from: http: www.gks.ru

10. National report on the progress and results of the implementation in 2019 of the State programs for the development of agriculture and regulation of markets for agricultural products, raw materials and food, Retrieved from: https: mcx.gov.ruuploadiblock98a98af7d467b718d07d5f1 38d4fe96eb6d.pdf

11. ASM: Production of auto and agricultural machinery for 2019, Retrieved from: https: aftershock.news? Q $=$ node $729841 \&$ full

12. F.F. Khuramshin, R.K. Sitdikov, Main directions of improving the agricultural leasing system, Bull. of Kazan State Agrar. Univ., 1, 10-13 (2012)

13. F.F. Khuramshin, Problems of agricultural leasing development, Competitiv. in the global world: econ., sci., technol., 3, 9-11 (2014)

14. Agriculture of Russia (Rosinformagrotech, Moscow, 2020), p. 53

15. N. Asadullin, F. Avkhadiev, I. Gainutdinov et al., Development of the agricultural sector in the republic of Tatarstan, Coll. BIO Web of Conf., Int. Sci.-Pract. Conf. Agriculture and Food Security: Technology, Innovation, Markets, Human Resources (FIES 2020) (2020), p. 00117 